\section{Embryo research}

The British House of Commons should this week settle for the government's bill on embryo research.

THE bill to give effect to the recommendations of the Warnock committee, now five years stale, reaches the House of Commons this week, perhaps even today (see opposite). That is why it is to be hoped that all concerned will pay more than passing attention to the article on page 768 of this issue, which carries one of the first formal reports to have appeared in print of the potential benefits of the manipulation of human embryos before they have been implanted into the uterus.

What Professor Robert Winston and Dr Alan Handyside have done is to exploit the property (well-known in, for example, the mouse) that not all the cells in an early embryo are necessary for its successful development. It is possible to take one cell from, say, the four-cell stage of the embryo's development, use that cell for making a diagnosis of the genetic condition of the embryo as a whole, and still look to the remaining cells to yield a viable fetus. What the work at the Hammersmith Hospital has shown is that it is possible to use this technique for screening embryos for their gender, using for implantation only female embryos, almost certain to be free from genetic defects linked with the X-chromosome, of which females carry two, one from each parent.

It is important and relevant to the Embryo Bill that it is entirely predicted that the technique would be effective: endless experiments with other mammals have given ample assurance that it would be. But this implies that the technique is an operational technique - a means of avoiding genetic defects that might otherwise be detectable only much later in pregnancy, perhaps resulting legitimately in abortion. It has been used, with approval of the voluntary committee set up to span the long wait for the Embryo Bill, and will no doubt be more generally applied when there is a legal framework in which other groups can operate. Defective embryos will, of course, be discarded. The ethical question for most people is whether the discarding of some out of several embryos at this stage is preferable to an abortion later. The House of Commons cannot be in much doubt where its decision should lie. In logic, those who support the present abortion law cannot easily oppose the Embryo Bill.

But that, of course, does not dispose of all the arguments. There are many who hold that neither abortion nor the manipulation of embryos should be allowed. The opinion, which has as a corollary the view that the birth of children with avoidable genetic defects is virtuous in some sense, deserves respect as a matter of civil comity. It is also relevant that, at least for recessive genes, there may be genetic arguments for caution: the disadvantages of the homozygote may be more easily recognized than the advantages of the heterozygote.

But that, fortunately, is but yet another argument for caution, which is one of the considerations that should weigh with the Licensing Authority which, the British Government proposes, will replace the voluntary committee that has stood in for it. And, properly briefed, that authority should give the lie to those who also argue that the manipulation of embryos before implantation is the beginning of a dangerous slippery slope.

\section{Journalist's dilemma}

The British press has been placed in an intolerable position by a court decision last week.

SUPPOSE a member of Nature's editorial staff were told on the telephone that a British computer manufacturer call it Chipmunk Ltd - had run out of cash and was trying to raise money from its bankers. Suppose that the recipient of this information then called the company to establish whether what he had been told was true. The precedent of a bizarre court case last week suggests the following course of events might follow. First, Chipmunk would apply to a High Court judge for an injunction to prevent publication of the news on the grounds that it would damage its commercial interests. Then, arguing that the information could come only from confidential documents, Chipmunk would demand that the journalist involved should reveal the name of his informant, meanwhile winning the courts' approval for a further injunction that Chipmunk's name should not be mentioned in any reports of its action. Relying on a strict interpretation of the Contempt of Court Act, 1981, which says that journalists may withhold the identity of the sources of their information except when disclosure is in the "national interest or the interest of justice", the court would then order the journalist to hand over his notebook on pain of being found guilty of contempt of court.

This is almost exactly what happened to Mr William Goodwin, a young journalist on The Engineer, who was fined $£ 5,000$ last week for his 'offence'. But the judges made it plain that he should count himself lucky; he might have been sent to jail for two years instead.

The puzzle in this is that the concept of justice seems to have become deranged. The original intention of the act was that journalists' freedom not to name their sources would be attenuated only when criminal prosecutions would thereby be impeded (which is itself offensive). In this case, while Chipmunk may have had a perfectly understandable wish to trace the leak of information, there can be no issue of justice involved.

Even if Chipmunk had a case for believing it would be damaged by publication, all damage has been prevented by the injunction on publication even of its name. Apart from the scant concern shown both by the law and by the judges who have interpreted it for the freedom of expression in Britain, the lesson of the Goodwin case will weigh with all potential whistle-blowers. If this is what the law means, it should be changed. 